\title{
ESTRATÉGIAS TERRITORIAIS CRIATIVAS
}

A criatividade tem sido frequentemente invocada, nos últimos anos, como um instrumento crucial do desenvolvimento das pessoas, das empresas, das cidades.

É complexo o significado de criatividade. Pode ligar-se a uma capacidade individual associada à imaginação e concretizada numa ideia ou objecto, mas também se pode entender como um recurso colectivo que permite encontrar novas soluções para os problemas de uma determinada comunidade ou respostas invulgares perante certos desafios. Em qualquer dos casos, a criatividade parece corresponder essencialmente ao 'power to connect the seemingly unconnected' (William Plomer, 1903-1973, escritor sul-africano). Estabelece 'pontes' originais e inesperadas, conferindo singularidade e distinção a pessoas, grupos e lugares, traços fundamentais para a sua afirmação num mundo crescentemente globalizado.

No âmbito do presente número da Finisterra, a criatividade é encarada como estímulo ao desenvolvimento local e regional, ou seja, é focada a sua dimensão colectiva e territorial. Assim, salienta-se, em especial, o papel da criatividade na produção de inovações que conduzem à transformação social das comunidades locais, bem como ao seu dinamismo económico. Estes processos são, cada vez mais, alimentados por via da cultura e das artes, não só porque estas actividades estimulam a imaginação e a inspiração, mas também porque facilitam a comunicação, utilizando uma vasta panóplia de linguagens.

As estratégias territoriais criativas implicam normalmente mudanças substantivas, quer em termos de valores e princípios orientadores da acção, quer ao nível das organizações e das políticas. Estas mudanças deparam-se normalmente com resistências mais ou menos fortes das instituições ou grupos que pretendem manter a situação anterior, ou porque lhes é mais favorável, ou porque a mudança comporta um risco que não pretendem correr. Mas a tensão frequente entre permanência e mudança - que se faz sentir quer nos pequenos grupos, como a família ou a pequena empresa, quer nos mais amplos e complexos, como as cidades - é geradora de conflitos. Aliás, podemos considerar que qualquer acto criativo gerador de uma inovação é um desafio à ordem estabelecida, é uma transgressão, mas é também a única fonte de mudança intencional. A tensão e o conflito estão assim intimamente ligados à criatividade e à inovação, surgindo como grandes oportunidades para a transformação social e económica.

Os vários artigos que compõem este número apresentam diferentes perspectivas da criatividade, todas ancoradas nas dinâmicas territoriais.

A maioria dos textos salienta o papel das políticas públicas, dos agentes e dos actores em ligação com as especificidades dos territórios, considerados em diferentes escalas. Klein, Fontan, Harrisson e Lévesque salientam, no $1^{\circ}$ artigo, o papel do modelo de governança do Québec - baseado numa ampla participação cívica e política, na cooperação entre múltiplos agentes e na economia plural, enquanto gerador 
de inovação sócio-territorial ao nível local e de transformação das próprias instituições. Harrisson, Comeau-Vallée e Chaari desenvolvem um exemplo do modelo de governança inovador apresentado no artigo anterior, a cooperação entre uma grande empresa pública (Hydro-Québec Distribution), a Action Réseau Consommateurs, a Coalition des Associations de Consommateurs du Québec e a Fédération des Associations Coopératives d'Économie Familiale (FACEF). Hamdouch e Depret discutem a inovação ambiental, associando a emergência e desenvolvimento da 'economia verde' à regulação pública e às dinâmicas particulares de diversos países - EUA, Japão, Dinamarca, França, Coreia do Sul e China. O artigo de Matos situa-se também no campo dos novos modelos de governança associados aos desafios da sustentabilidade urbana e especificamente ao movimento de transição.

Os dois últimos artigos focam o espaço urbano enquanto meio especialmente favorável à experimentação e à criatividade. Carmo introduz o debate sobre o pensamento anarquista, enquanto inspiração para a inovação social, apresentando três experiências urbanas: Fábrica Braço de Prata (Lisboa), Reclaim the Streets (Londres) e Critical Mass (São Francisco); salienta em particular a participação e a cidadania multi-escalar enquanto aspectos cruciais dessas experiências. Também no âmbito da inovação urbana, Machado e André discutem o exemplo de um meio socialmente criativo no bairro do Marais em Paris, sublinhando a importância do percurso histórico, do mix sociocultural e das políticas municipais no desenvolvimento de espaços públicos inovadores.

\section{TERRITORIAL CREATIVE STRATEGIES}

Creativity has often been evoked in recent years, as a crucial instrument for the development of people, firms and cities. Creativity is a complex concept. One can connect it to a single ability associated with imagination, and implemented as an idea or object, but one can also comprehend it as a collective resource that finds new solutions to the problems of a particular community, or as unusual responses to certain challenges. In any case, creativity seems to correspond essentially to the 'power to connect the seemingly unconnected' (William Plomer, 1903-1973, South-African writer). It establishes original and unexpected 'bridges', giving uniqueness and distinction to people, groups and places, which are fundamental traits to their status in an increasingly globalized world.

In the current issue of Finisterra, creativity is seen as incentive to regional and local development, i.e. with focus on its collective and territorial dimension. Thus, it is noted, in particular, the role of creativity in producing innovations that lead to social transformation of local communities as well as its economic dynamism. These processes are increasingly fed through culture and the arts, not only because these 
activities stimulate the imagination and inspiration but also because they facilitate communication by using a wide range of languages.

The creative territorial strategies typically involve substantial changes in terms of values and guiding principles of action, both in terms of organizations and policies. These changes are usually met with some resistance from institutions or groups wishing to maintain their status quo, either because it is more favourable or because the change involves a risk that they are unwilling to take. But the frequent tension between permanence and change - that is felt both in small groups, such as family or small business, or in broader and more complex ones such as the cities - generates conflicts. Furthermore, we consider that any creative act generating innovation is a challenge to the established order; it is a transgression but it is also the only source of intentional change. The tension and conflict are therefore closely linked to creativity and innovation, emerging as major opportunities for social and economic transformation.

The various articles that make up the current issue present different perspectives of creativity, all based on territorial dynamics

Most texts emphasize mainly the role of public policies, agents and actors in connection with the specificities of the territories at different scales. In the first paper, Klein, Fontan, Harrisson and Lévesque emphasize the role of the governance model of Québec - based on broad civic and political participation, on the cooperation among multiple agents and in the plural economy - as a generator of socio-territorial innovation at the local level and of change within the institutions. Harrisson, Comeau-Vallée and Chaari work on an example of innovative governance model presented in the previous article - the cooperation between a large public company (Hydro-Québec Distribution), the Action Réseau Consommateurs, the Coalition des Associations de Consommateurs du Québec and the Fédération des Associations Coopératives d'Économie Familiale (FACEF). Hamdouch and Depret discuss the environmental innovation, linking the emergence and development of "green economy" to public regulation and to the individual dynamic of various countries - USA, Japan, Denmark, France, South Korea and China. The article by Matos also refers to new governance models related to urban sustainability and specifically to the transition movement.

The last two articles focus on the urban space as an environment particularly favourable to experimentation and creativity. Carmo introduces the debate about anarchist thought as inspiration for social innovation, featuring three urban experiences: Fábrica Braço de Prata (Lisbon), Reclaim the Streets (London) and Critical Mass (San Francisco). He stresses, in particular, the participation and the multi-scale citizenship as crucial aspects of these experiences. Also within the scope of urban innovation, Machado and André discuss the creation of a socially creative environment in the Marais district in Paris, stressing the importance of the historical, sociocultural mix of municipal policies and the development of innovative public spaces.

Isabel André Maria João Alcoforado 